\title{
Abnormal Polyamine Metabolism in Hereditary Muscular Dystrophies
}

\author{
EFFECT OF HUMAN GROWTH HORMONE
}

\author{
Daniel Rudman, Michael H. Kutner, Rajender K. Chawla, and Martin A. \\ Goldsmith, Departments of Medicine, Biometry, and Pediatrics, \\ Emory University School of Medicine, and Clinical Research Facility, \\ Emory University Hospital, Atlanta, Georgia 30322
}

A B S TRACT Previous studies showed hyperresponsiveness to human growth hormone $(\mathrm{hGH})$ in men with myotonic or limb girdle dystrophies (MMD or LGD). Because polyamines may mediate some actions of hGH, we have now investigated polyamine metabolism in these and other dystrophies.

Under metabolic balance study conditions, serum and urine levels of putrescine $(\mathrm{Pu})$, spermidine $(\mathrm{Sd})$, spermine $(\mathrm{Sm})$, and cadaverine $(\mathrm{Cd})$ were measured in six normal men (36-44 yr), four men with MMD (38$44 \mathrm{yr}$ ), and three men with LGD (30-36 yr), before and during treatment with $0.532 \mathrm{U} / \mathrm{kg}$ body wt ${ }^{3 / 4} / \mathrm{d}$ of hGH. Daily balances of $\mathrm{N}, \mathrm{P}$, and $\mathrm{K}$ were also monitored. In the normal subjects, hGH did not influence elemental balances or serum and urine polyamines. In MMD, hGH caused significant retention of $\mathrm{N}, \mathrm{P}$, and $\mathrm{K}(P<0.005)$. Basal levels of $\mathrm{Sm}$ and $\mathrm{Cd}$ were significantly elevated above normal $(P<0.005)$, and $\mathrm{Pu}$, $\mathrm{Sm}$, and Cd increased two- to fourfold above basal during hGH treatment $(P<0.005)$. In LGD, hGH also caused retention of $\mathrm{N}, \mathrm{P}$, and $\mathrm{K}$. Basal levels of nearly all the polyamines (not serum $\mathrm{Pu}$ ) were significantly above normal in serum and urine $(P<0.05)$. During $\mathrm{hGH}$ treatment, all four polyamines rose significantly above basal $(P<0.005)$.

Serum and urine polyamine levels in five boys with Duchenne muscular dystrophy, age 8-13, did not differ from those in five age-matched normal boys.

Skeletal muscle polyamines were measured in five men (31-40 yr) without muscle disease and in three men with LGD (30-38 yr). Average concentrations of $\mathrm{Pu}, \mathrm{Sd}, \mathrm{Sm}$, and $\mathrm{Cd}$ were $46,306,548$, and $61 \mathrm{nmol} / \mathrm{g}$ wet wt in LGD and $1,121,245$, and 14 in the normal subjects, respectively $(P<0.05$ in each instance).

Received for publication 9 July 1.979 and in revised form 14 September 1.97 .9$.
Polyamines were determined in skeletal muscle, liver, kidney, and brain of male mice with hereditary muscular dystrophy and in age- and sex-matched normal controls. Pu, Sd, Sm, and Cd levels were two to three times higher than normal in muscle, but did not differ in liver, kidney, and brain. Similar findings were made in male hamsters with hereditary dystrophy and in their controls. The abnormality in hamster muscle polyamines appeared between 1 and $6 \mathrm{wk}$ of age and persisted or intensified until $30 \mathrm{wk}$.

These data reveal abnormalities of polyamine metabolism in men with MMD, in men with LGD, and in mice or hamsters with hereditary muscular dystrophy. The polyamine disorder could be related to dystrophic patients' hyperresponsiveness to hGH.

\section{INTRODUCTION}

In subjects with growth hormone $(\mathrm{GH})^{1}$ deficiency, injection of human $\mathrm{GH}(\mathrm{hGH})$ causes retention of $\mathrm{N}, \mathrm{P}$, and $K(1,2)$. The positive balances of these elements reflect expansion of the intracellular compartment with concomitant acceleration of protein synthesis. In normal individuals, any such effect at a given dose of $\mathrm{hGH}$ is $<10 \%$ as great as in GH-deficient individuals (1). Thus the latter patients are hyperresponsive to the anabolic effect of the hormone.

The mechanism by which GH stimulates protein synthesis probably involves the polyamines putrescine $(\mathrm{Pu})$, spermidine $(\mathrm{Sd})$, and spermine $(\mathrm{Sm})$, located in ribosomes and cytosol of all body cells in the form of polyamine-RNA $(3,4)$ and possibly polyamine-protein

\footnotetext{
${ }^{1}$ Abbreviations used in this paper: BW, body weight; Cd, cadaverine; DMD, Duchenne muscular dystrophy; GH, growth hormone; hGH, human GH; LGD, limb girdle muscular dystrophy; MMD, myotonic muscular dystrophy; $\mathrm{Pu}$, putrescine; $\mathrm{Sd}$, spermidine; $\mathrm{Sm}$, spermine.
} 
TABLE I

Clinical Data of the Dystrophic Patients Studied

\begin{tabular}{|c|c|c|c|c|c|}
\hline Subject & Experiment & Age & $\begin{array}{c}\text { Duration } \\
\text { of symptoms }\end{array}$ & $\begin{array}{l}\text { Functional } \\
\text { class (26) }\end{array}$ & $\begin{array}{c}\text { Muscle } \\
\text { score }(27)^{*}\end{array}$ \\
\hline & & $y r$ & $y r$ & & \\
\hline MMD1 & metabolic balance study & 42 & 20 & 4 & 290 \\
\hline MMD2 & metabolic balance study & 38 & 5 & 1 & 60 \\
\hline MMD3 & metabolic balance study & 44 & 12 & 3 & 190 \\
\hline MMD4 & metabolic balance study & 38 & 19 & 4 & 300 \\
\hline LGD1 & metabolic balance study & 30 & 10 & 3 & 220 \\
\hline LGD2 & metabolic balance study & 33 & 8 & 2 & 150 \\
\hline LGD3 & metabolic balance study & 36 & 6 & 1 & 80 \\
\hline LGD4 & muscle biopsy & 30 & 5 & 1 & 70 \\
\hline LGD5 & muscle biopsy & 38 & 7 & 1 & 90 \\
\hline LGD6 & muscle biopsy & 36 & 5 & 1 & 80 \\
\hline DMD1 & serum and urine PĄ & 8 & 5 & 2 & 70 \\
\hline DMD2 & serum and urine PA & 8 & 6 & 3 & 200 \\
\hline DMD3 & serum and urine PA & 9 & 5 & 2 & 190 \\
\hline DMD4 & serum and urine PA & 11 & 6 & 3 & 220 \\
\hline DMD5 & serum and urine PA & 13 & 8 & 4 & 300 \\
\hline
\end{tabular}

* Total loss of strength in all 68 muscles tested would give a score of 440 , total normality a score of 0 .

$\ddagger$ PA, polyamines.

complexes (5). (Cadaverine $[\mathrm{Cd}]$, produced by decarboxylation of lysine, is also present in some mammalian tissues.) GH stimulates the activity of ornithine decarboxylase, the rate-limiting enzyme in the biosynthesis of $\mathrm{Pu}, \mathrm{Sd}$, and $\mathrm{Sm}$, with resulting accumulation of polyamines in liver, kidney, and muscle $(6,7)$. Increased cellular content of polyamines is generally associated with accelerated protein synthesis (8-11), perhaps in part because polyamines promote formation of polysomes and retard degradation of RNA by ribonucleases $(3,12)$. In GH-deficient subjects, polyamines in serum and urine are subnormal, and are restored to normal by hGH (13). The hormone has little or no effect on polyamine levels in normal individuals.

Men with myotonic and limb girdle muscular dystrophies (MMD and LGD) are hyperresponsive to the anabolic action of $\mathrm{hGH}$, although they are not deficient in the endogenous hormone $(1,14)$. The mechanism for this hyperresponsiveness, which is comparable to that of GH-deficient subjects, is not known, but it could involve the polyamines. To investigate this possibility, we measured polyamines in the serum and urine of men with MMD and LGD, before and during hGH treatment. Elemental balances were also determined. The same experiments were done in normal agematched men as controls.

Boys with Duchenne muscular dystrophy (DMD) do not show anabolic hyperresponsiveness to hGH (15). For comparative purposes, serum and urine polyamines were determined in these and in age-matched normal boys.

Skeletal muscle polyamines were measured in three men with LGD (30-38 yr) and, for control purposes, in five normal men of similar age. Muscle polyamines were also measured in male mice and hamsters with hereditary muscular dystrophy, and their age-sexmatched controls.

\section{METHODS}

The subjects were: six normal men $(36-44 \mathrm{yr})$, five men (31-42 yr) without muscle disease undergoing elective laparotomy, four men with MMD (38-44 yr), six men with LGD (30-38 yr), five boys with DMD (6-15 yr), and five normal boys (8-13 yr). Criteria for diagnosis of MMD, LGD,

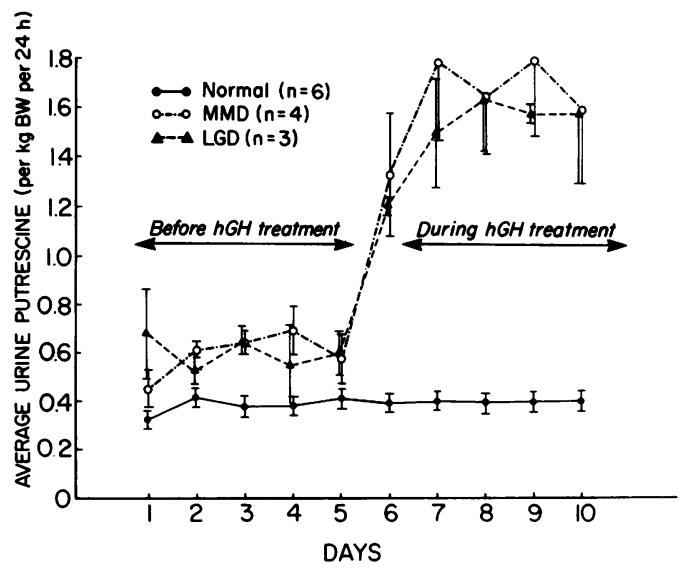

FIGURE 1 Average urinary excretion of putrescine ( $\mu$ moles per kilogram of body weight per day) by group and day (average $\pm \mathrm{SE}$ ). 
TABLE II

Summary of Polyamine Levels in Serum and Urine of Normal and Dystrophic Men during Metabolic Balance Studies

\begin{tabular}{|c|c|c|c|c|c|c|c|c|}
\hline & \multicolumn{4}{|c|}{ Serum } & \multicolumn{4}{|c|}{ Urine } \\
\hline & $\mathrm{Pu}$ & Sd & $\mathrm{Sm}$ & $\mathrm{Cd}$ & $\mathrm{Pu}$ & Sd & $\mathrm{Sm}$ & $\mathrm{Cd}$ \\
\hline & \multicolumn{4}{|c|}{ umollliter } & \multicolumn{4}{|c|}{$\mu m o l / k g B W / 24 h$} \\
\hline \multicolumn{9}{|l|}{ Period } \\
\hline \multicolumn{9}{|l|}{ Normals } \\
\hline Control & \multicolumn{4}{|c|}{$(12)$} & \multicolumn{4}{|c|}{ (30) } \\
\hline hGH & 0.32 & 0.28 & 0.0058 & 0.0092 & 0.40 & 0.14 & 0.0005 & 0.13 \\
\hline \multicolumn{9}{|l|}{ MMD } \\
\hline Control & 0.49 & \multicolumn{3}{|c|}{ (8) } & \multicolumn{4}{|c|}{$(20)$} \\
\hline hGH & $1.14 \ddagger$ & $0.12^{*}$ & $0.41 \ddagger$ & 0.15 & $1.63 \ddagger$ & $0.059^{*}$ & $0.146 \ddagger$ & 0.92 \\
\hline \multicolumn{9}{|l|}{ LGD } \\
\hline Control & 0.43 & $0.74 \ddagger$ & $0.45 \ddagger$ & 0.12 & \multicolumn{4}{|c|}{ (15) } \\
\hline hGH & $0.98 \ddagger$ & $1.34 \ddagger$ & $1.01 \ddagger$ & 0.30 & $1.51 \ddagger$ & $0.77 \ddagger$ & $0.076 \ddagger$ & 1.76 \\
\hline
\end{tabular}

Comparison

Normal group: control period vs. $\mathrm{hGH}$ period

$$
\text { SE }
$$

$P$

MMD group: control period

$$
\text { vs. hGH period }
$$

SE

$P$

LGD group: control period

$$
\text { vs. hGH period }
$$

$$
\text { SE }
$$$$
P
$$

$\pm 0.06 \quad \pm 0.05$

$$
\pm 0.05
$$$$
\pm 0.01
$$$$
\begin{array}{cr} 
\pm 0.05 & \pm 0.02 \\
\text { NS } & \text { NS }
\end{array}
$$$$
\begin{array}{cc} 
\pm 0.003 & \pm 0.06 \\
\text { NS } & \text { NS }
\end{array}
$$

$\pm 0.07 \quad \pm 0.06$

$$
\pm 0.07
$$$$
\pm 0.02
$$$$
\begin{array}{cc} 
\pm 0.06 & \pm 0.03 \\
0.005 & \text { NS }
\end{array}
$$$$
\begin{array}{r} 
\pm 0.003 \\
0.005
\end{array}
$$

0.005

NS

0.005

$\begin{array}{ccccccrr} \pm 0.09 & \pm 0.07 & \pm 0.09 & \pm 0.02 & \pm 0.07 & \pm 0.03 & \pm 0.004 & \pm 0.08 \\ 0.005 & 0.005 & 0.005 & 0.005 & 0.005 & 0.005 & 0.005 & 0.005\end{array}$

Normal group (control period)

vs. MMD group (control period)

$$
\text { SE }
$$

$P$

$\begin{array}{cccc} \pm 0.07 & \pm 0.06 & \pm 0.08 & \pm 0.02 \\ \text { NS } & \text { NS } & 0.005 & 0.005\end{array}$ $\pm 0.03$

NS $\pm 0.08$

0.005

Normal group (control period)

vs. LGD group (control period)

$\begin{array}{lcccrrrrr}\mathrm{SE} & \pm 0.07 & \pm 0.06 & \pm 0.09 & \pm 0.02 & \pm 0.08 & \pm 0.03 & \pm 0.006 & \pm 0.08 \\ P & \text { NS } & 0.005 & 0.005 & 0.005 & 0.05 & 0.005 & 0.005 & 0.005\end{array}$

In the upper half of the table, values represent mean value for each polyamine and numbers in parentheses equal number of observations. In the lower half, $P$ values and SE for each multiple comparison are given.

* Significantly lower than normal from previous report $(13)(P<0.05)$.

I Significantly higher than normal from previous report $(13)(P<0.005)$.

and DMD have been given previously $(1,14,15)$. Clinical data of the dystrophic patients are summarized in Table I.

Metabolic balance studies were performed (1). After a 3-d equilibration to the standard diet, daily balances of $\mathrm{N}, \mathrm{P}$, and $\mathrm{K}$ were measured during a 5-d control period followed by a 5 -d period of hGH $\left(0.532 \mathrm{U} / \mathrm{kg}\right.$ body wt $\left.[\mathrm{BW}]^{3 / 4} / \mathrm{d}\right)$ (National
Pituitary Agency). Urine was collected every $24 \mathrm{~h}$ at $0^{\circ} \mathrm{C}$ for measurement of $\mathrm{Pu}, \mathrm{Sd}, \mathrm{Sm}$, and $\mathrm{Cd}$ (13); fasting serum levels of these compounds were determined (13) on the last $2 \mathrm{~d}$ of control and hGH periods. Urine from the boys with DMD and the normal boys was collected while they were on an ad lib. hospital diet. 
TABLE III

Summary of Elemental Balances during the Metabolic Balance Studies in Normal and Dystrophic Men

\begin{tabular}{|c|c|c|c|}
\hline & $\Delta \mathbf{K}$ & $\Delta \mathrm{P}$ & $\Delta \mathbf{K}$ \\
\hline & $g$ & $g$ & $m e q$ \\
\hline \multicolumn{4}{|l|}{ Period } \\
\hline \multicolumn{4}{|l|}{ Normals } \\
\hline Control & 0.084 & $\begin{array}{l}0.0063 \\
(30)\end{array}$ & 0.25 \\
\hline hGH & 0.073 & 0.0031 & 0.28 \\
\hline \multicolumn{4}{|l|}{ MMD } \\
\hline Control & 0.046 & $\begin{array}{l}0.0095 \\
(20)\end{array}$ & 0.13 \\
\hline hGH & 0.662 & 0.0569 & 2.55 \\
\hline \multicolumn{4}{|l|}{ LGD } \\
\hline Control & 0.097 & $\begin{array}{l}0.0001 \\
(15)\end{array}$ & 0.12 \\
\hline hGH & 0.611 & 0.0569 & 2.46 \\
\hline \multicolumn{4}{|c|}{ Comparison } \\
\hline \multicolumn{4}{|c|}{$\begin{array}{l}\text { Normal group: control period } \\
\text { vs. hGH period }\end{array}$} \\
\hline SE & \pm 0.09 & \pm 0.007 & \pm 0.12 \\
\hline$P$ & NS & NS & NS \\
\hline \multicolumn{4}{|c|}{$\begin{array}{l}\text { MMD group: control period } \\
\text { vs. } \mathrm{hGH} \text { period }\end{array}$} \\
\hline $\mathrm{SE}$ & \pm 0.11 & \pm 0.009 & \pm 0.15 \\
\hline$P$ & 0.005 & 0.005 & 0.005 \\
\hline \multicolumn{4}{|c|}{$\begin{array}{l}\text { LGD group: control period } \\
\text { vs. hGH period }\end{array}$} \\
\hline SE & \pm 0.13 & \pm 0.010 & \pm 0.17 \\
\hline$P$ & 0.005 & 0.005 & 0.005 \\
\hline \multicolumn{4}{|c|}{$\begin{array}{l}\text { Normal group (control period) } \\
\text { vs. MMD group (control } \\
\text { period) }\end{array}$} \\
\hline $\mathrm{SE}$ & \pm 0.10 & \pm 0.008 & \pm 0.13 \\
\hline$P$ & NS & NS & NS \\
\hline \multicolumn{4}{|c|}{$\begin{array}{l}\text { Normal group (control period) } \\
\text { vs. LGD group (control } \\
\text { period) }\end{array}$} \\
\hline SE & \pm 0.11 & \pm 0.008 & \pm 0.15 \\
\hline$P$ & NS & NS & NS \\
\hline
\end{tabular}

In the upper half of the table, values represent mean values for $\Delta N, \Delta P$, and $\Delta K$, and numbers in parentheses equal number of observations. $\Delta N, \Delta P$, and $\Delta K$ are expressed as grams, grams and milliequivalents, respectively, per kilogram BW per day. In the lower half, $P$ values and SE for each multiple comparison are given.

Polyamines (16), N (17), P (18), and K (19) were measured in muscle removed from three men with LGD under local anesthesia; and in muscle removed from five men without muscle disease during elective laparotomy under general anesthesia because of cholelithiasis (2), myoma of the stomach
(1), lipoma of the mesentery (1), or renal cyst (1). Light microscopy of these specimens showed changes consistent with LGD in the former three cases, and normal structure in the latter five.

The clinical studies were done with approval of Emory 

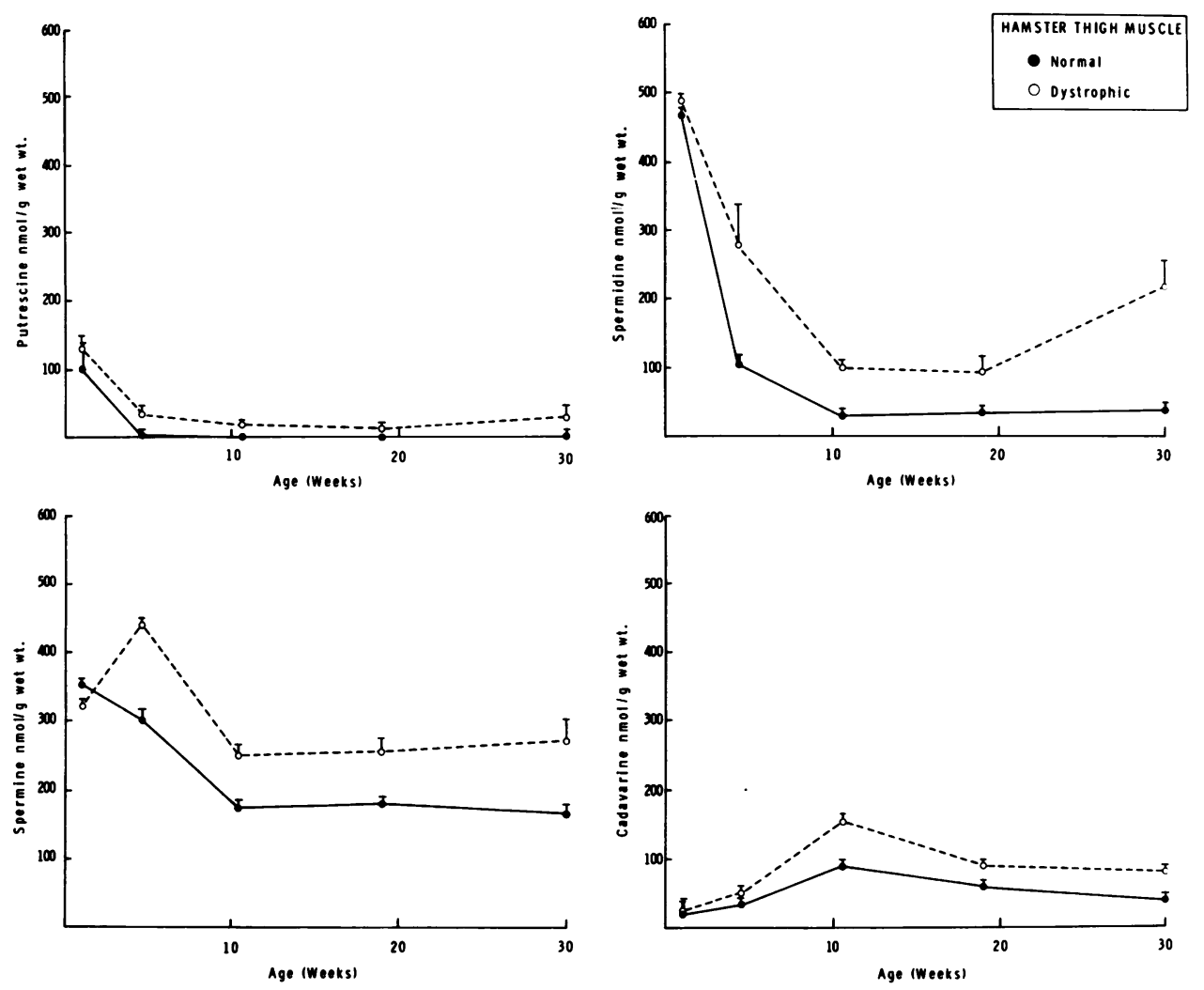

FIGURE 2 Concentrations of polyamines in thigh muscle of normal and dystrophic hamsters from 1 to $30 \mathrm{wk}$ of age.

University's Clinical Trials Committee and with the informed consent of subject or parents, as appropriate.

Dystrophic and normal male mice (strain 129/ReJ-dy), age $10 \mathrm{wk}$, were obtained from The Jackson Laboratory, Bar Harbor, Maine, and fed Purina rat chow (Ralston Purina Co., St. Louis, Mo.) ad lib. They were killed by decapitation; polyamines (16) and total $N(17)$ were measured in a pool of three thigh muscles (vastus lateralis, vastus intermedius, rectus femoris), liver, kidney, and brain. Similar studies were done in dystrophic (Bio 14,6) and control male hamsters, age 1-50 wk, obtained from BioResearch Consultants, Cambridge, Mass., and fed Purina rat chow ad lib. In addition to polyamines and N, P (18) and K (19) were also determined in the hamster thigh muscles.

Statistical methods. A single-factor repeated measures analysis was performed on each of the dependent variables $(\Delta \mathrm{N}, \Delta \mathrm{P}, \Delta \mathrm{K}$, urine and plasma polyamines). The grouping factor consisted of the normals (six), the MMD (four), and the LGD (three), over 10 timed periods (five before hGH treatment and five during hGH treatment). Five multiple comparisons were made in each analysis using the Bonferonni procedure. Standard errors for each comparison were estimated using the appropriate error term from the analyses of variance (see Fig. 1 and Tables II and III).

A two-factor analysis of variance was performed for each muscle polyamine in the hamster. The factors were the groups (normal and dystrophic) and time in weeks. The average value for each group was then compared at each time period (Fig. 2) (20).

\section{RESULTS}

Metabolic balance studies in normal men, and in men with MMD and LGD. Data are summarized in Tables II and III. The data for individual patients are deposited with the National Auxiliary Publications Service. ${ }^{2}$

In the normal men, serum and urine $\mathrm{Pu}, \mathrm{Sd}$, and $\mathrm{Sm}$ levels fell within the $95 \%$ prediction limits reported for normal age-adjusted subjects (13). The normal ranges of serum and urine Cd levels, not previously reported, were now found to be $0.00-0.02 \mu \mathrm{mol} / \mathrm{liter}$ and $0.08-0.20 \mu \mathrm{mol} / \mathrm{kg} \mathrm{BW}$ per $24 \mathrm{~h}$, respectively. The balances of N, P, and $\mathrm{K}$ were close to zero. During $5 \mathrm{~d}$ of treatment with hGH, no significant change $(P>0.05)$

${ }^{2}$ An Appendix has been deposited with the National Auxiliary Publications Service (NAPS) as NAPS document 03555. This information may be ordered from ASIS/NAPS, Microfiche Publications, P. O. Box 3513, Grand Central Station, New York 10017. Remit in advance, in U. S. funds, $\$ 3.00$ for microfiche copy, or for photocopy, $\$ 5.00$ up to 20 pages plus $25 \notin$ for additional pages. Outside the U. S. and Canada add postage of $\$ 3.00$ for photocopy and $\$ 1.00$ for microfiche. Checks should be made payable to Microfiche Publications. 
occurred in $\mathrm{N}, \mathrm{P}$, or $\mathrm{K}$ balance (confirming previous reports $[1,2])$ or in serum and urine polyamine levels.

In the four men with MMD, serum and urine polyamine profiles differed from the normal controls in this study and in previously reported experiments (13). In serum and urine, $\mathrm{Sm}$ and $\mathrm{Cd}$ were significantly elevated $(P<0.005)$ and $\mathrm{Sd}$ was significantly depressed ( $P$ $<0.05)$. The degrees of elevation above the normal mean were twofold or more. Elemental balances during the control period were essentially zero. During treatment with $\mathrm{hGH}$, serum and urine $\mathrm{Pu}, \mathrm{Sm}$, and $\mathrm{Cd}$ increased two- to threefold $(P<0.05)$, only $S d$ remaining unchanged. $\mathrm{N}, \mathrm{P}$, and $\mathrm{K}$ were retained in significant amounts, the ratios averaging $0.66 \mathrm{~g} / 0.057 \mathrm{~g} / 2.55 \mathrm{meq}$ (confirming previous studies $[1,2]$ ).

In the three men with LGD, the basal levels of Sd, $\mathrm{Sm}$, and $\mathrm{Cd}$ were all elevated in serum and urine $(P$ $<0.005$ ). Elemental balances before hGH treatment were close to zero. During hGH treatment, serum and urine levels of $\mathrm{Pu}, \mathrm{Sd}, \mathrm{Sm}$, and Cd increased two- to threefold $(P<0.005) ; \mathrm{N}, \mathrm{P}$, and $\mathrm{K}$ were retained in significant amounts [average, $0.61 \mathrm{~g} / 0.057 \mathrm{~g} / 2.46 \mathrm{meq}$ ], confirming an earlier study (14).

Polyamine means in histologically dystrophic muscle from three men with LGD were markedly higher ( $P$ $<0.05$ ) than in histologically normal muscle from five men of similar age (Table IV).

DMD vs. normal boys (Table V). The normal serum and urine levels of $\mathrm{Pu}, \mathrm{Sd}$, and $\mathrm{Sm}$ conformed to the previously described normal range (13). Normal levels of $\mathrm{Cd}$ in serum and urine were: 0.00-0.02 $\mu \mathrm{mol} / \mathrm{liter}$ and $0.17-0.93 \mu \mathrm{mol} / \mathrm{kg}$ per BW per $24 \mathrm{~h}$, respectively. In boys with DMD, serum and urine polyamine levels showed no significant differences from normal.

Dystrophic vs. normal mice. Polyamines in liver, kidney, and brain did not differ between the two groups (Table IV). In dystrophic skeletal muscle, polyamines were significantly higher than in normal muscle $(P$ $<0.05$ ), whereas concentration of total $\mathrm{N}$ was not statistically different.

Dystrophic vs. normal hamsters. At 14 wk, levels of polyamines in liver, kidney, and brain were not significantly different between the two groups (Table IV). In dystrophic thigh muscles, all four polyamines were significantly elevated, whereas concentrations of $\mathrm{N}, \mathrm{P}$, and $\mathrm{K}$ were not statistically different from normal (data for $\mathrm{P}$ and $\mathrm{K}$ not shown).

Muscle polyamines were then measured in both

TABLE IV

Tissue Concentrations of Polyamines

\begin{tabular}{|c|c|c|c|c|c|c|c|}
\hline Species & Status & Tissue & $\mathbf{N}$ & $\mathrm{Pu}$ & Sd & $\mathrm{Sm}$ & $\mathrm{Cd}$ \\
\hline & & & $\begin{array}{l}g / 100 \mathrm{~g} \\
d r y w t\end{array}$ & & nmollg wet & & \\
\hline \multirow{8}{*}{$\begin{array}{l}\text { Mouse, age } 10 \mathrm{wk} \\
\quad(n=4)\end{array}$} & Normal & Muscle & $13.1 \pm 0.5$ & 0 & $157 \pm 6$ & $81 \pm 15$ & 0 \\
\hline & Dystrophic & Muscle & $12.5 \pm 0.6$ & $29 \pm 16$ & $302 \pm 12$ & $238 \pm 12$ & $95 \pm 7$ \\
\hline & Normal & Liver & & $4 \pm 4$ & $1,339 \pm 44$ & $1,260 \pm 64$ & 0 \\
\hline & Dystrophic & Liver & & $8 \pm 6$ & $1,416 \pm 81$ & $1,369 \pm 119$ & 0 \\
\hline & Normal & Kidney & & $59 \pm 16$ & $563 \pm 34$ & $1,222 \pm 46$ & 0 \\
\hline & Dystrophic & Kidney & & $51 \pm 6$ & $597 \pm 68$ & $1,082 \pm 74$ & 0 \\
\hline & Normal & Brain & & $26 \pm 3$ & $634 \pm 23$ & $474 \pm 13$ & 0 \\
\hline & Dystrophic & Brain & & $22 \pm 4$ & $593 \pm 96$ & $406 \pm 63$ & 0 \\
\hline \multirow{8}{*}{$\begin{array}{l}\text { Hamster, age } 14 \text { wk } \\
\quad(n=8)\end{array}$} & Normal & Muscle & $13.3 \pm 0.6$ & 0 & $37 \pm 2$ & $176 \pm 6$ & $94 \pm 8$ \\
\hline & Dystrophic & Muscle & $12.4 \pm 0.5$ & $15 \pm 4$ & $103 \pm 9$ & $249 \pm 15$ & $156 \pm 13$ \\
\hline & Normal & Liver & & 0 & $334 \pm 17$ & $682 \pm 16$ & 0 \\
\hline & Dystrophic & Liver & & 0 & $357 \pm 13$ & $674 \pm 14$ & 0 \\
\hline & Normal & Kidney & & 0 & $444 \pm 4$ & $677 \pm 5$ & 0 \\
\hline & Dystrophic & Kidney & & 0 & $454 \pm 9$ & $674 \pm 13$ & 0 \\
\hline & Normal & Brain & & $15 \pm 1$ & $496 \pm 4$ & $351 \pm 4$ & 0 \\
\hline & Dystrophic & Brain & & $14 \pm 1$ & $507 \pm 26$ & $380 \pm 24$ & 0 \\
\hline \multirow[t]{8}{*}{ Human-muscle } & LGD & deltoid & 12.1 & 34 & 344 & 609 & 59 \\
\hline & LGD & deltoid & 13.6 & 44 & 306 & 583 & 78 \\
\hline & LGD & deltoid & 11.4 & 59 & 268 & 453 & 45 \\
\hline & Cholelithiasis & rectus abdominis & 14.0 & $\mathbf{0}$ & 185 & 293 & 0 \\
\hline & Cholelithiasis & rectus abdominis & 11.2 & 2 & 128 & 196 & 20 \\
\hline & Gastric myoma & rectus abdominis & 12.2 & 0 & 84 & 219 & 30 \\
\hline & Mesenteric lipoma & rectus abdominis & 11.6 & 4 & 79 & 300 & 12 \\
\hline & Diaphragmatic hernia & rectus abdominis & 14.1 & 6 & 59 & 253 & 0 \\
\hline
\end{tabular}

All animal values are average $\pm S E$. 
TABLE V

Serum and Urine Polyamines in Five Boys with DMD and in Five Age-Matched Normal Boys

\begin{tabular}{|c|c|c|c|c|c|c|c|c|}
\hline & \multicolumn{4}{|c|}{ Serum } & \multicolumn{4}{|c|}{ Urine } \\
\hline & $\mathbf{P u}$ & Sd & $\mathrm{Sm}$ & Cd & $\mathbf{P u}$ & Sd & $\mathrm{Sm}$ & $\mathrm{Cd}$ \\
\hline & \multicolumn{4}{|c|}{ umol/liter } & \multicolumn{4}{|c|}{$\mu \mathrm{mol} / \mathrm{kg} B W / 24 \mathrm{~h}$} \\
\hline DMD & $0.55 \pm 0.07$ & $0.49 \pm 0.06$ & $0.22 \pm 0.05$ & $0.01 \pm 0.004$ & $1.09 \pm 0.13$ & $0.25 \pm 0.05$ & $0.02 \pm 0.004$ & $0.32 \pm 0.05$ \\
\hline Normal & $0.58 \pm 0.06$ & $0.55 \pm 0.04$ & $0.24 \pm 0.03$ & $0.01 \pm 0.004$ & $1.10 \pm 0.16$ & $0.25 \pm 0.04$ & $0.02 \pm 0.007$ & $0.43 \pm 0.14$ \\
\hline
\end{tabular}

Average $\pm \mathrm{SE}, n=5$.

groups at 1, 6, 19, and 30 wk (Fig. 2). In normals, $\mathrm{Pu}$, $\mathrm{Sd}$, and $\mathrm{Sm}$ declined with age. In contrast, $\mathrm{Cd}$ rose to a peak at $11 \mathrm{wk}$, then declined slightly. A similar but less pronounced pattern was found in the dystrophic hamsters. At $1 \mathrm{wk}$, muscle polyamine levels were similar to normal. At all ages after $6 \mathrm{wk}$, the $\mathrm{Pu}, \mathrm{Sd}$, and $\mathrm{Sm}$ values, although declining with age (with the exception of $\mathrm{Pu}$ at $6 \mathrm{wk}$ ), remained significantly higher than normal $(P<0.05)$. Although $\mathrm{Pu}$ nearly disappeared from normal muscle after $6 \mathrm{wk}$, it persisted at an average of $20-40$ $\mathrm{nmol} / \mathrm{g}$ wet tissue in dystrophic muscle. In the latter tissue, the level of $\mathrm{Cd}$ was significantly higher than normal after $11 \mathrm{wk}(P<0.05)$.

\section{DISCUSSION}

Before hGH treatment, the levels of polyamines in serum and urine in MMD and LGD differed from normal and from each other. In MMD, serum and urine Sd and Cd levels were elevated and Sm was depressed; in LGD, the levels of nearly all the polyamines (except serum $\mathrm{Pu}$ ) were increased. An additional abnormality in polyamine metabolism of MMD and LGD became apparent during $\mathrm{hGH}$ treatment. Although the hormone caused no change in serum or urine polyamine levels in normals, in men with MMD and LGD it produced significant increases in all polyamines, except Sd in MMD.

Further evidence for abnormal polyamine metabolism in LGD was provided by the muscle analyses, which showed elevations comparable to those in serum and urine. This comparison is not definitive because only three LGD specimens were studied. However, a conclusive demonstration of elevated polyamines in two types of genetically dystrophic skeletal muscle was observed in the mouse and hamster. In both forms of rodent dystrophy, the difference in polyamine profile between diseased and normal muscle generally resembled that between LGD and normal muscle of man. In both rodents, the polyamine profile remained normal in liver, kidney, and brain. The pathologic accumulation of polyamines in dystrophic hamster muscle began between 1 and $6 \mathrm{wk}$ after birth and thereafter persisted or intensified with age.

How is the polyamine abnormality in men with
MMD and LGD related to their hyperresponsiveness to hGH? The polyamine disturbance could be the result of a primary hyperresponsiveness of the dystrophic muscle cells to the hormone. The well-known in vitro effects of GH on muscle (21) suggest that this tissue probably possesses specific $\mathrm{GH}$ receptors. Accordingly, we can postulate an increased number or affinity of hGH receptors in MMD and LGD muscle cells. Then the basal increase in polyamines could result from hyperresponsiveness to endogenous $\mathrm{GH}$, and the further increment in polyamines during $\mathrm{hGH}$ treatment could reflect hyperresponsiveness to exogenous GH. Alternatively, a polyamine abnormality could be the cause and hyperresponsiveness to hGH could be the effect. Such a primary disorder in polyamine metabolism could be any of the following: $(a)$ overactivity in one or more enzymes of polyamine biosynthesis $(4,22) ;(b)$ deficient activity in enzyme(s) responsible for oxidizing $(4,22)$ or conjugating the polyamines $(23)$; (c) augmented binding of polyamines by cytoplasmic proteins or RNA $(3,5)$. Then the observed increased basal levels of polyamines would result. Furthermore, because polyamines may be the intracellular mediators for some of the anabolic actions of GH (4), the accumulation of polyamines might cause the muscle cells to be hyperresponsive to exogenous hGH.

Females with MMD and normal menstrual function do not exhibit anabolic hyperresponsiveness to hGH, apparently because endogenous estrogens inhibit this reaction to the hormone (2). It will be of interest to study serum and urine polyamines in such women before and during hGH treatment.

After the completion of this study, data on $\mathrm{Pu}, \mathrm{Sd}$, and $\mathrm{Sm}$ in skeletal muscle of dystrophic mice and patients were published by Kremzner et al. (24). They found accumulations of polyamines in dystrophic mouse muscle at $1.5-8$ wk generally similar to those reported here at $10 \mathrm{wk}$. In two of three cases of LGD, muscle $\mathrm{Pu}$ and Sd levels were reported by Kremzner et al. (24) to be higher than in controls; muscle $\mathrm{Pu}, \mathrm{Sd}$, and $\mathrm{Sm}$ levels in MMD were stated to be within the normal range. Ages of patients and controls, however, were not given, and it is not clear whether these groups were age matched. In view of the age dependence of 
polyamines in hamster (Fig. 2) and rat (25), our data on muscle polyamines in 30-44 yr-old men without muscle disease and with LGD or MMD cannot readily be compared with those of Kremzner and co-workers (24) in subjects of unstated age.

\section{ACKNOWLEDGMENT}

This work was supported by U. S. Public Health Service grant RR39.

\section{REFERENCES}

1. Rudman, D., S. B. Chyatte, J. H. Patterson, G. G. Gerron, I. O'Beirne, J. Barlow, P. Ahmann, A. Jordan, and R. C. Mosteller. 1971. Observations on the responsiveness of human subjects to human growth hormone. Effects of endogenous growth hormone deficiency and myotonic dystrophy. J. Clin. Invest. 50: 1941-1949.

2. Heymsfield, S. B., R. A. Bethel, and D. Rudman. 1977. Hyperresponsiveness of patients with clinical and premyopathic myotonic dystrophy to human growth hormone. J. Clin. Endocrinol. Metab. 45: 147-158.

3. Bachrach, U. 1973. Polyamines and nucleic acids. In Function of Naturally Occurring Polyamines. Academic Press, Inc., New York. 63-73.

4. Raina, A., and J. Janne. 1975. Physiology of the natural polyamines putrescine, spermidine and spermine, Med. Biol. (Helsinki). 53(3): 121-147.

5. Liang, T., G. Mezzett, C. Chen, and S. Liao. 1978. Selective polyamine-binding proteins: spermine binding by an androgen-sensitive phosphoprotein. Biochim. Biophys. Acta. 524: 430-441.

6. Russell, D. H., and S. H. Snyder. 1969. Amine synthesis in regenerating rat liver: effect of hypophysectomy and growth hormone on ornithine decarboxylase. Endocrinology. 84: 223-228.

7. Kostyo, J. L. 1966. Changes in polyamine content of rat liver following hypophysectomy and treatment with growth hormone. Biochem. Biophys. Res. Commun. 23: $150-155$.

8. Russell, D. 1973. Polyamines in growth. In Polyamines in Normal and Neoplastic Growth. D. Russell, editor, Raven Press, New York. 1-13.

9. Raina, A., and J. Janne. 1970. Polyamines and the accumulation of RNA in mammalian systems. Fed. Proc. 29: 1568-1574.

10. Bachrach, U. 1973. Regulatory functions of polyamines, In Function of Naturally Occurring Polyamines, Academic Press, Inc., New York. 82-95.

11. Bachrach, U. 1973. Effect on growth processes. In Function of Naturally Occurring Polyamines, Academic Press, Inc., New York. 56-62.

12. Levy, C. C., W. E. Mitch, and M. Schmukler. 1973.
Effect of polyamines on a ribonuclease which hydrolyzes ribonucleic acid at uridylic acid residues. J. Biol. Chem. 248: 5712-5719.

13. Rudman, D., M. Kutner, R. Chawla, M. Goldsmith, R. D. Blackston, and R. Bain. Serum and urine polyamines in normal and short children.J. Clin. Invest. 64: 1661-1668.

14. Rudman, D., S. B. Chyatte, G. G. Gerron, I. O'Beirne, and J. Barlow. 1972. Hyperresponsiveness of patients with limb girdle dystrophy to human growth hormone. J. Clin. Endocrinol. Metab. 35: 256-260.

15. Rudman, D., S. B. Chyatte, J. H. Patterson, G. G. Gerron, I. O’Beirne, J. Barlow, A. Jordan, and J. S. Shavin. 1972. Metabolic effects of human growth hormone and of estrogens in boys with Duchenne muscular dystrophy. J. Clin. Invest. 51: 1118-1124.

16. Marton, L. J., D. H. Russell, and C. C. Levy. 1973. Measurement of putrescine, spermidine and spermine in physiological fluids by use of an amino acid analyzer. Clin. Chem. 19: 923-926.

17. Steyermark, A. 1961. Quantitative Organic Microanalysis. Academic Press, Inc., New York. 188-208.

18. Boltz, D. F. 1958. Colorimetric Determination of NonMetals. Wiley Interscience Div., New York. 29-46.

19. Analytical Methods for Atomic Absorption Spectrophotometry. Perkin-Elmer Corp., Norwalk, Conn. K-1971, 1-2.

20. Winer, B. J. 1971. Statistical Principles in Experimental Design. 2nd edition., McGraw-Hill Book Co., New York. 5: 309-430, 7: 514-603.

21. Mills, J. B., C. R. Reagan, D. Rudman, J. L. Kostyo, P. Zachariah, and A. E. Wilhelmi. 1973. Metabolic effects of plasmin digests of human growth hormone in the rat and man. J. Clin. Invest. 52: 2941-2951.

22. Bachrach, U. 1973. Metabolism of the polyamines. In Function of the Naturally Occurring Polyamines. Academic Press, Inc., New York. 96-107.

23. Tabor, H., C. W. Tabor. 1972. Biosynthesis and metabolism of 1,4-diaminobutane, spermidine, spermine, and related amines. Adv. Enzymol. Relat. Areas Mol. Biol. 36: 203-268.

24. Kremzner, L. T., V. M. Tennyson, and A. F. Miranda. 1978. Polyamine metabolism in normal, denervated and dystrophic muscle. In Advances in Polyamine Research. R. A. Campbell, D. R. Morris, D. Bartos, G. D. Daves, and F. Bartos, editors. 241-256.

25. Janne, J., A. Raina, M. Siimes. 1964. Spermidine and spermine in rat tissues at different ages. Acta Physiol. Scand. 62: 352-358.

26. Swinyard, C. A., G. C. Deaver, and L. Greenspan. 1957. Gradients of functional ability of importance in rehabilitation of patients with progressive muscular and neuromuscular diseases. Arch. Phys. Med. Rehabil. 38: 574-579.

27. Lilienfeld, A. M., M. Jacobs, and M. Willis. 1954. A study of the reproducibility of muscle testing and certain other aspects of muscle scoring. Phys. Ther. Rev. 34: 279-289. 